ORIGINAL ARTICLE

\title{
A study on awareness and practices of bio-medical waste management in tertiary care hospital
}

MOHAMMAD SHAKIL AHMAD ${ }^{1 *}$

${ }^{1}$ Department of Community Medicine and Public Health, College of Medicine, Majmaah University, Al Majmaah 11952 , Saudi Arabia. ${ }^{*}$ Correspondence to: Dr Mohammad Shakil Ahmad, Assistant Professor, Department of Community Medicine and Public Health, College of Medicine, Majmaah University, Al Majmaah 11952, Saudi Arabia; Email: m.shakil@mu.edu.sa

\begin{abstract}
Introduction: Bio-Medical Waste (BMW) consists of solids, liquids, sharps and laboratory waste that are potentially infectious and dangerous. In India, lack of knowledge and practice in relation to availability of resources and processes in place has been reported in many studies. Hence, the present study has been carried out with an objective of assessing awareness and practices of healthcare providers regarding BMW.

Materials and methods: This cross-sectional study was conducted in tertiary care hospital with 300 beds in Karnataka over a period of one month using preformed, pre-structured proforma.

Results: Almost all health personnel were aware about BMW guidelines; adequate segregation of BMW was noticed in only 4 sites (11.8\%).

Conclusion: The awareness about BMW management among healthcare providers in our study was found to be adequate but with low segregation practices. The staffs are well aware to manage the spills and will use if all the sites are provided with spill kits.

Key words: Biomedical waste, color coding, India, tertiary hospital, waste segregation
\end{abstract}

\section{INTRODUCTION}

The term "health-care waste" refers to all wastes generated by medical procedures in health-care facilities, research centers, and laboratories. It also includes the same sorts of waste generating from modest and scattered sources, such as waste generated during home health care (e.g., home dialysis, self-administration of insulin, and recuperative care). ${ }^{1}$

Bio-Medical Waste (BMW) is comprised of potentially infectious and harmful solids, liquids, sharps, and laboratory waste. Poor health-care waste management, according to the World Health Organization (WHO), puts health-care personnel, waste handlers, patients, and the general public at danger of infection, harmful effects, and injuries, as well as damaging the environment. All medical waste materials must be separated at the point of creation, processed appropriately, and disposed of safely. ${ }^{2}$

India generates around 3 million tonnes of medical waste every year and the amount is expected to grow at 8 $\%$ annually. ${ }^{3}$ The Government of India has laid down biomedical management and handling rules 1998 and has been revised in $2016 .{ }^{4}$

In India, lack of knowledge and practice in relation to availability of resources and processes in place has been reported in many studies. The proper techniques for handling of waste and practice of safety measures can prevent healthcare providers as well as community in general from various adverse effects of hazardous waste. ${ }^{3,5}$ With this background the present study has been carried out with an objective of assessing awareness and practices of healthcare providers regarding BMW.

\section{MATERIAL AND METHODS}

This cross-sectional study was conducted in a tertiary care hospital in Belgaum, Karnataka with 300 beds over a period of one month from December $1^{\text {st }} 2021$ to $30^{\text {th }}$ December 2020. Different facilities like wards, Intensive care units (ICU's), operation theatres (OTs), emergency, outpatient departments, laboratories and injection room were evaluated for collection, segregation, storage, transportation and disposal of BMW. A preformed, prestructured proforma was administered on laboratory technicians, radiographers, nursing and ward maintenance staff to collect the data regarding awareness and practices of handling and disposal of BMW. The proforma was divided into 2 parts, first part included questions on awareness of healthcare workers and second part envisaged on healthcare workers practices. Awareness on needle stick injuries, spill management, disposal of laboratory reagents was assessed. Evaluation included availability of BMW bins, liners, puncture-proof containers, spill kits, personal protective equipment's, hand-washing facility, disinfectant solutions, segregation, storage, facility for transportation, disposal and information, education and communication materials. The data collected was entered and analysed using SPSS 17 . Requisite permission and ethical clearance were obtained from the concerned authorities.

\section{RESULTS}

The BMW was generated at 34 sites in the hospital which included 14 wards, 10 out-patient departments, 4 laboratories and 4 intensive care units and 2 operation theatres. (Table 1)

Table 1: Sites of situation analysis in the hospital

\begin{tabular}{|l|l|l|}
\hline & Frequency & Percentage (\%) \\
\hline Ward & 14 & 41.1 \\
\hline OPD & 10 & 29.4 \\
\hline Lab & 4 & 11.8 \\
\hline ICU & 4 & 11.8 \\
\hline OT & 2 & 5.9 \\
\hline Total & 34 & 100.0 \\
\hline
\end{tabular}

Table 2 shows awareness about BMW among the hospital staff. Almost all health personnel were aware about BMW guidelines but only $35.3 \%$ said to have 
undergone a training programme; half of the study participants reported to have training in spill management. Majority $(88.2 \%)$ of them were aware regarding postexposure prophylaxis but only half reported that they will seek treatment from Integrated Counselling and Testing Centres.

Table 2: Awareness about biomedical waste management

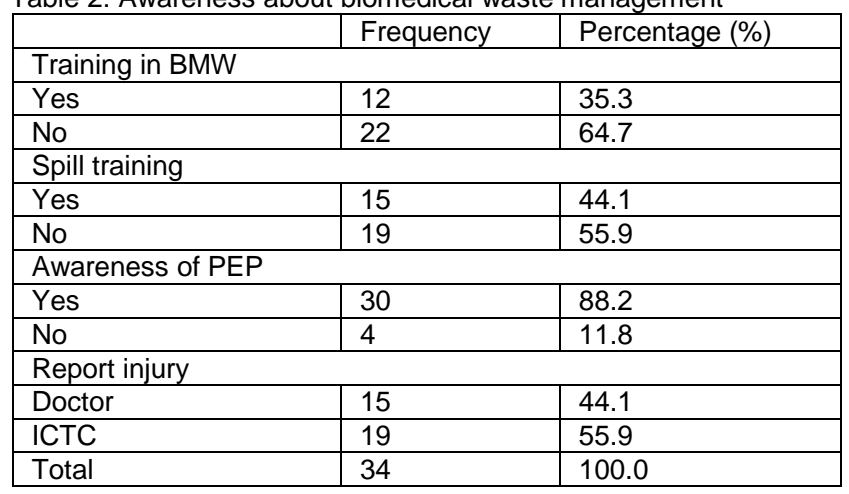

Table 3: Observation findings of BMW

\begin{tabular}{|c|c|c|}
\hline & Frequency & Percentage (\%) \\
\hline \multicolumn{3}{|c|}{ Puncture proof container } \\
\hline Available & 26 & 76.5 \\
\hline Not available & 8 & 23.5 \\
\hline \multicolumn{3}{|c|}{ Disinfectant solution } \\
\hline Available & 22 & 64.7 \\
\hline Not available & 12 & 35.3 \\
\hline \multicolumn{3}{|c|}{ BMW Chart displayed } \\
\hline Available & 20 & 58.8 \\
\hline Not available & 14 & 41.2 \\
\hline \multicolumn{3}{|c|}{ Spill protocol chart displayed } \\
\hline Available & 9 & 26.5 \\
\hline Not available & 25 & 73.5 \\
\hline \multicolumn{3}{|l|}{ Blood spill kit } \\
\hline Available & 9 & 26.5 \\
\hline Not available & 25 & 73.5 \\
\hline \multicolumn{3}{|c|}{ Mercury spill kit } \\
\hline Available & 4 & 11.8 \\
\hline Not available & 30 & 88.2 \\
\hline \multicolumn{3}{|l|}{ PPE } \\
\hline Available & 32 & 94.1 \\
\hline Not available & 2 & 5.9 \\
\hline \multicolumn{3}{|l|}{ Segregation } \\
\hline Yes & 4 & 11.8 \\
\hline No & 30 & 88.2 \\
\hline \multicolumn{3}{|l|}{ Covered bins } \\
\hline Yes & 29 & 85.3 \\
\hline No & 5 & 14.7 \\
\hline \multicolumn{3}{|l|}{ Duration } \\
\hline 24 & 30 & 88.2 \\
\hline 48 & 4 & 11.8 \\
\hline \multicolumn{3}{|c|}{ Hand washing facility } \\
\hline Available & 21 & 61.8 \\
\hline Not available & 13 & 38.2 \\
\hline Total & 34 & 100.0 \\
\hline
\end{tabular}

As per the post-exposure prophylaxis for needle stick injuries in Kayakalpa guidelines ${ }^{6}$ by Government of Karnataka, the part should be cleaned with running water and soap and should not be squeezed. But, in the present study 7 individuals reported to squeeze and let 1-2 drops of blood, majority however said they will report to Integrated Counselling and Testing Centres and get investigated and treated accordingly. More than half of the study population $(58.8 \%)$ reported to use spill kits for managing blood and body fluid spills. However, on observation, spill kit was available only at 9 of 34 sites. The hospital does not have a reagent disposal protocol and majority of the staff reported that they have limited or no knowledge in this regard. The laboratory reagents and disinfectant solutions were sent back to the pharmacy or let in the drain without any pretreatment. Only 7 sites had all the required colour coded bins as per the guidelines, whereas, in other sites less or inadequate bins were noticed. Only in Anti-Retroviral Treatment (ART) centre site broken pieces of glassware were managed according to guidelines and hub cutter was used. Injury register was also maintained at ART centre.

Table 3 depicts the observation findings of BMW management in the hospital. Puncture-proof container and disinfectant solution was available at $26(76.5 \%)$ and 22 $(64.7 \%)$ sites respectively. There was lack of display of BMW segregation charts in 14 sites $(41.2 \%)$ and spill management chart not available in 25 (73.5\%) sites; blood spill kit was present in $9(26.5 \%)$ sites and mercury spill kit in $4(11.8 \%)$ sites. Personal protective equipment's were available in 32 sites and staff reported that mask and cap were usually less in quantity. Adequate segregation of BMW was noticed in only 4 sites $(11.8 \%)$, however majority 29 (85.3) of the sites had bins covered with lids. In majority of the sites waste was collected and disposed every 24 hours. Twenty-one sites had a hand washing facility for the healthcare personal.

\section{DISCUSSION}

The International Clinical Epidemiology Network reviewed BMW practices set-up and framework in all healthcare facilities across India and reported that more than $50 \%$ of healthcare facilities have no proper BMW system in place. ${ }^{7}$ The Bio-Medical Management and Handling rules have been laid down 1998 and subject to amendments and modifications (2016) with an aim to minimize cross infection, improve the general hygiene in hospitals and to curtail environmental pollution through proper treatment and disposal of waste. ${ }^{8}$

The successful implementation of these rules rests on awareness and practices of healthcare workers. Many studies have documented the importance of audit and training of healthcare workers for effective implementation of the guidelines. Hence the present study is an effort in this regard to contribute to the existing body of literature and also substantiate the need for repeated training and monitoring activities.

In the present study the awareness and practices regarding bio-medical waste management among health care workers was high among nurses and paramedical staff and the same is corroborated by studies conducted in tertiary care hospitals in Amritsar ${ }^{9}$, Jaipur ${ }^{10}$ and Delhi ${ }^{11}$.

In the current scenario only $35 \%$ of the healthcare 
workers had undergone training on BMW management. The proper and suitable management of biomedical waste necessitates the training of both technical and nontechnical personnel. A person who gets a needle stick injury from a needle used on an infected source patient has a 30\%, 1.8 percent, and 0.3 percent chance of contracting $\mathrm{HBV}, \mathrm{HCV}$, and HIV, respectively. ${ }^{2}$ The reporting of injuries resulting from needle stick injuries was found to be low among the study participants (44\%). According to Stein et al ${ }^{12}$, about $37 \%$ of doctors and nurses have ever experienced a needle stick injury. The fact that most technical and nontechnical employees are uninformed of a formal system of injury reporting, which should be created inside all health facilities, may account for the low reporting of injuries. Many studies opined that necessity of effective practical training and adequate theoretical knowledge is required among both medical and paramedical health care workers for overall improvement of biomedical waste management and handling practices. ${ }^{13,14}$

The most important stage in efficient BMW management is proper segregation, which includes having enough waste containers in the right number, in the right places, and with the right color code. The presence of the incorrect type of waste in a particular container will definitely negate the efforts of proper waste disposal. In spite of the crucial importance of segregation at the point of waste generation in the present study a low level of segregation practices were noted $(11.8 \%)$. Contrasting results have been reported in the previous studies with some authors reporting good and some bad segregation practices. ${ }^{15,16}$ Previous studies have reported a better knowledge and practices among nurses and lab technicians. ${ }^{17,18}$ Waste segregation practices were found to be good in a study conducted by Patil GV et al in a 574-bed tertiary care Medical Institute in Belgaum, Karnataka, India. 19

In the present study, the use of electrically operated needle cutters to mutilate the used needles and nozzle (hub) of used syringes was significantly lower. Similar finding has been observed by a study conducted by Kumar $R$ et al in North India. ${ }^{20}$

More than half of the study population (58.8\%) reported to use spill kits for managing blood and body fluid spills. However, on observation, spill kit was available only at 9 of 34 sites in the hospital.

With adequate training personal protective measures can help greatly to reduce injuries with sharps and needles and in turn protect healthcare workers from blood borne infections causes by HIV virus, Hepatitis B virus and Hepatitis $C$ virus. In our study in most of the sites, gloves and mask were available with a deficiency of apron and footwear. In a study done in Davangere, Karnataka the staff were using apron in $2 \%$ and gloves in $20 \%$ of the sites. ${ }^{21}$

\section{CONCLUSION}

The awareness about BMW management among healthcare providers in our study was found to be adequate but low segregation practices. The staffs are well aware to manage the spills and will use if all the sites are provided with spill kits.

Recommendations: The poor BMW practices, health and environmental effects are attributed to lack of training and awareness among healthcare providers. Repeated training and supportive monitoring of healthcare workers is necessary for effective BMW.

Acknowledgements: We are thankful to the hospital management for permitting us to conduct the study. We acknowledge the hospital staff for their cooperative coordination and support during the study.

Conflict of interest: none declared

Source of funding: nil

\section{REFERENCES}

1. Safe management of wastes from health-care activities / edited by Y. Chartier et al. - 2nd ed.

2. Healthcare waste. World Health Organization. Accessed on $2^{\text {nd }}$ Aug 2018. Available from: http://www.who.int/en/news$\mathrm{room} /$ fact-sheets/detail/health-care-waste

3. Mathur V, Dwivedi S, Hassan MA, Misra RP. Knowledge, attitude and practices about biomedical waste management among healthcare personnel- a cross-sectional study. Indian J Community Med 2011;36(2):143-5.

4. Government of India. Ministry of Environment and Forest gazette notification No. 460 dated July 27 New Delhi 1998:10-20

5. David JJ, Shanbag P. Awareness and practices regarding biomedical waste management among healthcare workers in a tertiary care hospital in Delhi: comment. Indian J Med Microbiol 2016;34:391-2

6. Kayakalpa guidelines. Government of Karnataka. Accessed on $2^{\text {nd }}$ Aug 2018. Available from: http://nhm.gov.in/images/pdf/infocus/Revised Kayakalp Guidelines.pdf

7. INCLEN Program Evaluation Network (IPEN) study group, New Delhi, India. Biomedical waste management: situational analysis and predictors of performance in 25 districts across 20 India states. Indian J Med Res 2014;139:141-53

8. Bio-Medical Waste Management Rules, 2016. Published in the Gazette of India, Extraordinary, Part II, Section 3, SubSection (i), Government of India Ministry of Environment, Forest and Climate Change. Notification; New Delhi, the $28^{\text {th }}$ March, 2016

9. Bhagawati G, Nandwani S, Singhal S. Awareness and practices regarding bio-medical waste management among health care workers in a tertiary care hospital in Delhi. Indian J Med Microbio. 2015;33(2):580-2.

10. Narang RS, Manchanda A, Singh S, Verma N, Padda S. Awareness of biomedical waste management among dental professionals and auxiliary staff in Amritsar, India. Oral Health Dent Manag. 2012;11:162-8.

11. Sharma A, Sharma V, Sharma S, Singh P. Awareness of biomedical waste management among health care personnel in Jaipur, India. Oral Health Dent Manag. 2013;12(1):32-40.

12. Stein AD, Makarawo TP, Ahmad MF. A survey of doctors and nurses' knowledge, attitudes and compliance with infection control guidelines in Birmingham teaching hospitals. J Hosp Infect 2003;54:68-73.

13. Mohapatra A, Gupta M, Shivalli S, Mishra CP, Mohapatra SC. Biomedical waste management practices of doctors: An online snapshot. Natl J Community Med. 2012;3:227-31.

14. Pandit NB, Mehta HK, Kartha GP, Choudhary SK. Management of bio-medical waste: Awareness and practices in a district of Gujarat. Indian J Public Health. 2005;49:245-7.

15. Rao PH: Hospital waste management system - a case study of a south Indian city. Waste Manag Res 2009, 27:313-321.

16. Nataraj G, Baveja S, Kuyare S, Poojary A, Mehta PK: Report: medical students for monitoring biomedical waste 
segregation practices - why and how? Experience from a medical college. Waste Manag Res 2008, 26:288-290.

17. Deo D, Tak SB, Munde SS. A study of knowledge regarding biomedical waste management among employees of a teaching hospital in rural area. J Indian Soc Hospital Waste Management. 2006;5(1):12-6.

18. Saini S, Nagarajan SS, Sharma RK. Knowledge, attitude and practices of bio-medical waste management amongst staff of a tertiary level hospital in India. J Academy Hospital Administration. 2005;17(2):1-12.
19. Patil GV, Pokhrel K: Biomedical solid waste management in an Indian hospital: a case study. Waste Manag 2005, 25:592-599.

20. Kumar R, Gupta AK, Aggrawal AK, Kumar A. A descriptive study on evaluation of bio-medical waste management in a tertiary care public hospital of North India. Journal of Environmental Health Science \& Engineering 2014;12:69.

21. Anuroopa SM. A study on hospital waste management in Davangere city, dissertation submitted to the Rajiv Gandhi University of Health Sciences, Bangalore, Department of Community Medicine, J. J. M. Medical College, Davangere. 